\title{
Estimasi Jumlah Stok Karbon Yang Tersimpan di Lahan Basah Desa Sungai Tohor Kecamatan Tebing Tinggi Timur Kabupaten Kepulauan Meranti Provinsi Riau
}

\author{
Maizaldi $^{1}$, Bintal Amin ${ }^{1}$, Joko Samiaji ${ }^{1}$ \\ ${ }^{1}$ Fakultas Perikanan dan Ilmu Kelautan Universitas Riau \\ Kampus Bina Widya Panam KM 12.5 Pekanbaru, Telp. 0761-28293
}

\begin{abstract}
The research was conducted from July to December 2018 which aims to estimate the amount of carbon stock storage in wetland ecosystems that cover the near shore (mangrove) to upper land (peatland) in Sungai Tohor Village. Survey method was applied and sampling was done by non-destructive method that is without harvesting, so as not to change the ecological function of the forest. Data of carbon pool biomass was analysed and calculated in laboratory with allometric equations to extrapolate biomass. The results showed that the total carbon stock storage in the wetland ecosystem that covered the mangrove area to the peat area was equal to 51499.10 tons $C /$ ha and was able to absorb CO2 by 70901.78 tons $\mathrm{CO} 2 / \mathrm{ha}$. The largest total carbon deposits are in the mangrove region which is equal to 31525.83 tons C/ha, while the peat region has the ability to store lower carbon with a total value of 19973.27 tons C/ha.
\end{abstract}

\section{Key Words: carbon storage, mangrove, peatland, wetland, Sungai Tohor Village}

Ekosistem lahan basah (wetland) merupakan salah satu ekosistem yang paling produktif dengan tingkat keanekaragaman hayati yang tinggi baik akuatik maupun terestrial. Namun demikian kondisi ekosistem ini mulai cukup memprihatinkan dan terus mengalami penurunan peran dan fungsi akibat dari berbagai aktivitas manusia yang pada akhirnya berkontribusi besar dalam peningkatan emisi gas rumah kaca. Mengingat fungsinya yang sangat penting yakni sebagai sistem penyangga kehidupan, sumber air, sumber pangan, habitat margasatwa, serta berperan sebagai pengendali iklim global dan risiko bencana, ekosistem ini mulai menjadi sorotan dunia dalam hal perbaikan pengelolaannya.

Sebagian besar wilayah Desa Sungai Tohor berupa lahan basah yang didominasi oleh lahan gambut, yakni seluas \pm 75.000 ha. Kegiatan deforestasi dan pembuatan kanal disinyalir mengganggu stabilitas ekosistem lahan basah di Desa Sungai Tohor dalam perannya sebagai penyerap karbon khususnya pada lahan gambut dan hutan mangrove. Hal tersebut diperkirakan secara potensial akan berpengaruh pada perairan sekitarnya. Saat suatu lahan yang pada awalnya bervegetasi berubah menjadi tidak bervegetasi maka proses penyerapan $\mathrm{CO}_{2}$ menjadi hilang. $\mathrm{CO}_{2}$ yang terakumulasi langsung ke perairan akan mengurangi input oksigen ke perairan atau bahkan tidak ada sama sekali sehingga dapat membahayakan organisme perairan khususnya hewan bentik yang sifatnya tidak aktif (pergerakan terbatas). Jika dilindungi pada kondisi alami ekosistem lahan basah dapat berperan dalam menyerap karbon, namun sebaliknya jika mengalami gangguan akan berpotensi menjadi sumber karbondioksida $\left(\mathrm{CO}_{2}\right)$, metana $\left(\mathrm{CH}_{4}\right)$ dan nitrous oksida $\left(\mathrm{N}_{2} \mathrm{O}\right)$ dalam jumlah yang cukup besar.

Kajian perhitungan jumlah stok karbon yang tersimpan di lahan basah menjadi perlu untuk dilakukan sebagai upaya untuk memprediksi potensi cadangan karbon yang masih tersimpan pada saat tertentu dan perubahannya apabila terjadi kegiatan yang berpotensi dalam menambah atau mengurangi luasan wilayah. Penelitian mengenai estimasi stok karbon dan analisis biomassa pernah dilakukan di wilayah Kabupaten Kepulauan Meranti. Suryanta et al. (2016) menjelaskan bahwa stok karbon yang tersimpan di Kepulauan Meranti dengan luas wilayah 3.709 
$\mathrm{km}^{2}$ adalah sebanyak 811.588.035,06 ton ditambah tanah mineral menjadi \pm 811.605.580,06 ton pada kedalaman rata-rata kurang dari $5 \mathrm{~m}$. Namun demikian, dalam penelitian tersebut tidak dilakukannya perhitungan jumlah stok karbon dan biomassa di wilayah Desa Sungai Tohor yang notabene merupakan bagian dari Kabupaten Kepulauan Meranti yang saat ini dijadikan sebagai lokasi prioritas utama dalam rangka program restorasi gambut yang diprogramkan oleh pemerintah pusat.

Mengacu pada permasalahan tersebut, maka penelitian ini berfokus pada kajian mengenai estimasi atau perhitungan stok karbon pada ekosistem lahan basah yang melingkupi wilayah near shore yakni mangrove hingga ke wilayah upper land yakni gambut di Desa Sungai Tohor.

Jumlah cadangan karbon pada setiap lokasi berbeda-beda tergantung dari karakteristik lahan, keanekaragaman dan kerapatan tumbuhan yang ada. Perbedaan zonasi pada ekosistem mangrove berpengaruh pada jenis dan kerapatan vegetasi yang terdapat di dalamnya. Begitupun yang terjadi pada ekosistem daratan yang memiliki jenis dan kerapatan vegetasi yang berbeda-beda pula. Adanya kerapatan dan jenis vegetasi yang berbeda akan menggambarkan potensi $\mathrm{CO}_{2}$ yang mampu diserap tanaman pada suatu ekosistem, sehingga dapat diketahui besaran kontribusi yang diberikan oleh lahan basah Desa Sungai Tohor sebagai penyimpan stok karbon.

\section{BAHAN DAN METODE}

Penelitian ini dilaksanakan pada bulan Juli Desember 2018 yang bertempat di Desa Sungai Tohor Kecamatan Tebing Tinggi Timur Kabupaten Kepulauan Meranti Provinsi Riau. Pengukuran biomassa dan kandungan karbon terikat dilakukan di Laboratorium Kimia Laut Fakultas Perikanan dan Kelautan Universitas Riau, Pekanbaru. Lokasi yang dipilih pada penelitian ini adalah ekosistem lahan basah yang melingkupi wilayah mangrove (near shore) hingga ke wilayah gambut (upper land) di Desa Sungai Tohor.

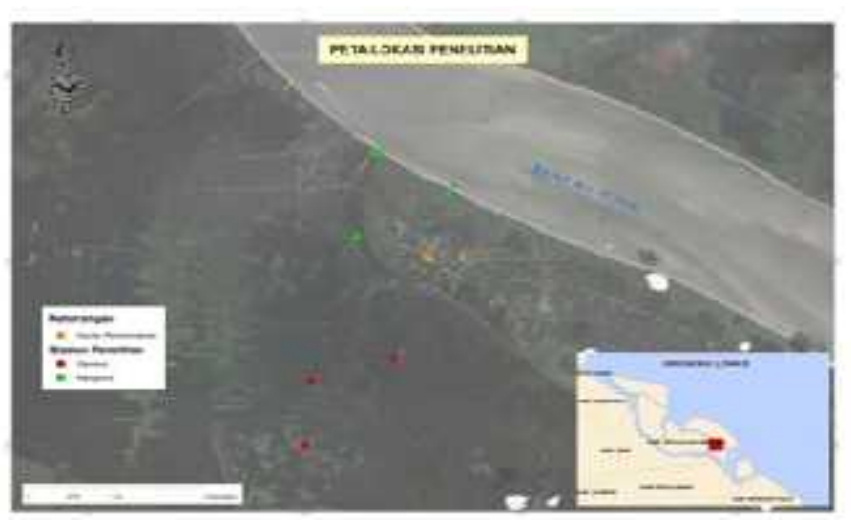

Gambar 1. Peta Lokasi Penelitian

Adapun alat dan bahan yang digunakan dalam penelitian ini diantaranya sebagai berikut : GPS, kompas, tally sheet, phi band, bor gambut (untuk mengukur kedalaman gambut), meteran $50 \mathrm{~m}$, tali rafia, paralon $1 / 2$ ' diameter $50 \times 50 \mathrm{~cm}$ (plot serasah), kantong plastik, timbangan, parang, alat tulis (spidol, papanjalan, pensil), kertas label, alumunium foil dan oven. Bahan yang digunakan untuk penelitian ini adalah data diameter setinggi dada (DBH) dan sampel tanah yang diambil dari jarak pesisir pantai (near shore) hingga wilayah upperland.

Tahapan penelitian terbagi menjadi 2 tahapan yakni pengukuran langsung dilapangan (pengukuran DBH pohon) dan analisis sampel di laboratorium. Teknik pengambilan sampel dilakukan dengan menggunakan metode non destructive yakni pengukuran tanpa melakukan pengrusakan pada tanaman. Pengumpulan data stok karbon diinventarisasi dari sumber carbon pools masing-masing wilayah yakni karbon biomassa dan kandungan organik tanah. Sampling data stok karbon biomassa dan organik tanah pada wilayah mangrove (near shore) dilakukan dengan menggunakan metode purposive sampling terbagi dalam 3 zona yakni lower, middle dan upper zone yang mengacu pada Badan Standarisasi Nasional (2011). 


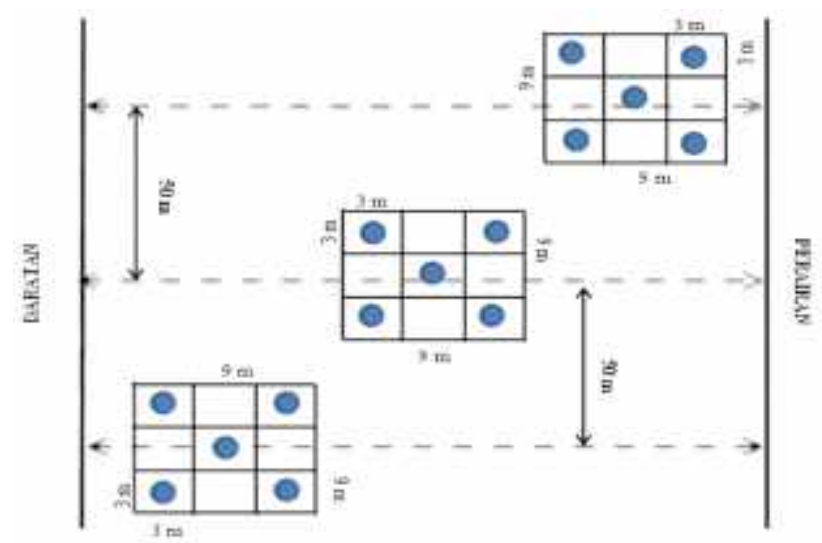

Gambar 2. Plot Transek dan Petakan Contoh Pengambilan Sampel di Wilayah Mangrove

Sampling untuk data stok karbon biomassa dan organik tanah pada wilayah gambut (upper land) dilakukan dengan metode acak terbagi dalam 3 stasiun dan mengikuti prosedur yang ditentukan oleh Kauffman et al., (2016) mengacu pada Istomo (2006).

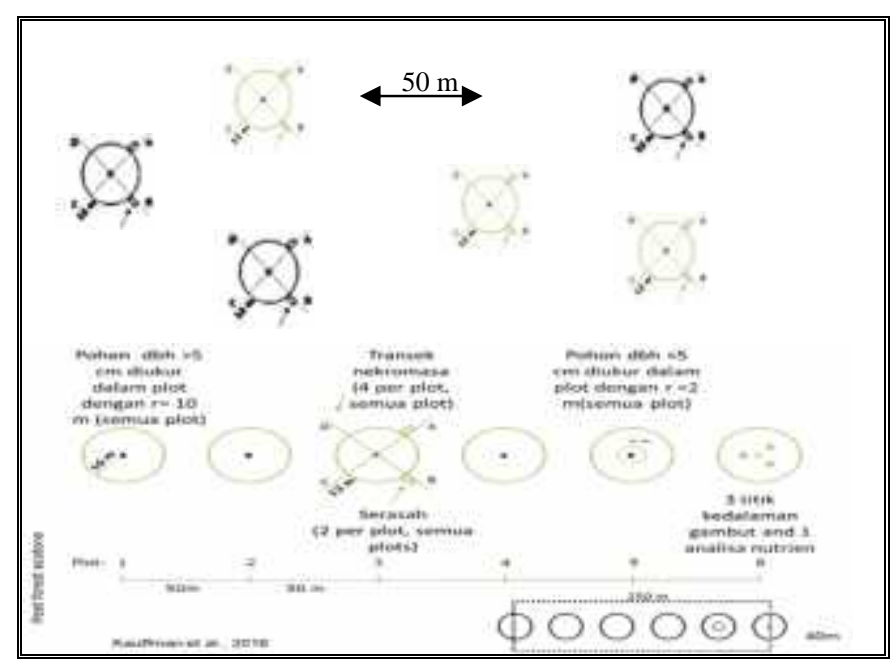

Gambar 3. Plot Transek dan Petakan Contoh Pengambilan Sampel di Wilayah Gambut

Adapun parameter yang diukur dalam penelitian ini adalah komposisi vegetasi dan nilai kerapatannya (mengacu pada Soerianegara dan Indrawan, 2005), diameter pohon, jumlah serasah, nekromassa dan kandungan organik tanah di masing-masing stasiun pada ekosistem lahan basah Desa Sungai Tohor. Selanjutnya data yang diperoleh dianalisis di laboratorium dan disajikan dalam bentuk persamaan allometrik yang dibangun berdasarkan hubungan antara parameter pohon, yaitu diameter pohon, tinggi batang total, dan berat jenis kayu dengan biomassa. a. Pendugaan biomassa karbon masingmasing stasiun pada wilayah mangrove (near shore) dihitung dengan menggunakan persamaan alometrik yakni:

1. Biomassa bagian atas yang dipakai untuk semua spesies (Komiyama et al.,2005)

$$
\mathrm{B}=0,251 \text { p } \times \text { D2,46 }
$$

2. Biomassa bagian atas untuk spesies Rhizophora apiculata (Amira, 2008)

$$
B=0.043 \times \text { D2.63 }
$$

3. Biomassa Bagian Bawah (Komiyama et al.,2005)

\section{$\mathrm{B}=0,199 \times \mathrm{p} 0,899 \times \mathrm{DBH}$}

b. Sedangkan pendugaan biomassa karbon masing-masing stasiun pada wilayah gambut (upperland) dihitung dengan menggunakan persamaan alometrik yang mengacu kepada Istomo (2006) yakni :

Biomassa $=0,136 \mathrm{D} 2$

Biomassa karbon dikonversi menjadi ton/ha dan dilakukan penentuan Frekuensi Error.

c. Selanjutnya kandungan karbon dari biomassa masing - masing stasiun dihitung dengan menggunakan rumus yang mengacu pada Badan Standardisasi Nasional (2011) yaitu:

\section{$\mathrm{Cb}=\mathrm{B} \times \% \mathrm{C}$ Organik}

Keterangan: $\mathrm{Cb}$ adalah kandungan karbon dari biomassa, dinyatakan dalam kilogram $(\mathrm{kg})$; B adalah total biomassa, dinyatakan dalam $(\mathrm{kg})$; dan \%C organik adalah nilai persentase kandungan karbon, sebesar 0.47 atau menggunakan nilai persen karbon yang diperoleh dari hasil pengukuran di laboratorium.

1. Estimasi total stok karbon yang tersimpan di lahan basah Desa Sungai Tohor dihitung dengan menggunakan rumus yang mengacu pada Badan Standardisasi Nasional (2011) yaitu :

$$
\mathbf{C}_{\text {total }}=\mathbf{C}_{\mathbf{n}}+\mathbf{C}_{\text {tanah }}
$$

Keterangan : $\mathrm{Cn}$ adalah total kandungan karbon biomassa

2. Perhitungan daya serapan gas $\mathrm{CO}_{2}$ masingmasing stasiun pada ekosistem lahan basah dihitung dengan menggunakan rumus yang mengacu pada Bismark et al., (2008) yaitu: 


\section{$\mathrm{SCO}_{2}=\frac{\mathrm{Mr} \cdot \mathrm{CO}_{2}}{\mathrm{Ar} \cdot \mathrm{C}} \times \mathrm{KC}$}

Keterangan : $\mathrm{S} \mathrm{CO}_{2}$ adalah serapan gas $\mathrm{CO} 2$ $(\mathrm{kg}) ; \mathrm{Mr}$. $\mathrm{CO} 2$ adalah berat molekul senyawa $\mathrm{CO}_{2}$, yakni 44; Ar. $\mathrm{C}$ adalah berat molekul relatif atom $\mathrm{C}$, yakni 12 ; Kc adalah kandungan karbon, dinyatakan dalam kilogram (kg).

\section{HASIL}

Parameter Kualitas Perairan. Berdasarkan hasil penelitian nilai parameter suhu masingmasing stasiun menunjukkan kisaran suhu perairan tropik yakni berkisar antara $27-30^{\circ} \mathrm{C}$. Selanjutnya parameter salinitas masing-masing stasiun berkisar antara 24-26\%o dan $\mathrm{pH}$ masingmasing stasiun berkisar antara 6,0-7,0.

\section{Komposisi Vegetasi dan Nilai}

Kerapatan. Komposisi vegetasi yang ditemukan di wilayah mangrove terdiri atas 3 spesies dalam 69 jumlah individu, yaitu: Rhizophora apiculata, Bruguiera farviflora, Avicennia alba sebanyak 16 individu. Sedangkan komposisi vegetasi yang teridentifikasi di wilayah gambut sebanyak 60 spesies dalam 384 jumlah individu.

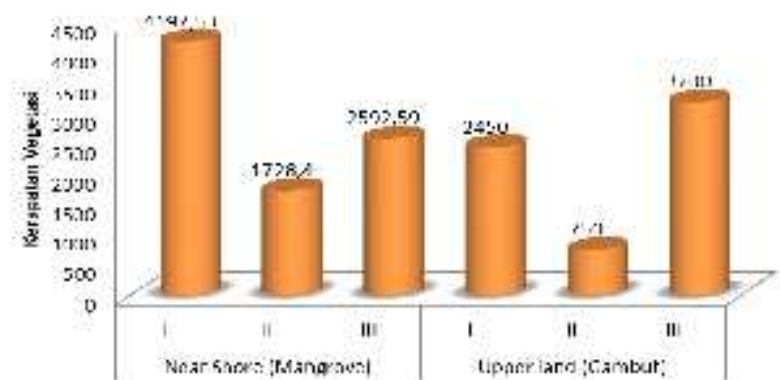

Grafik 1. Kerapatan Vegetasi Pada Wilayah Mangrove (Near Shore) Hingga Wilayah gambut (Upper

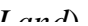

Total Stok Karbon yang Tersimpan Pada Ekosistem Lahan Basah. Adapun pendugaan total stok karbon yang tersimpan pada ekosistem lahan basah Desa Sungai Tohor didapat dari hasil perhitungan jumlah kandungan kabon yang di inventarisasi dari total biomassa tanaman dan kandungan organik tanah pada masing-masing stasiun. Biomassa pohon merupakan penjumlahan dari kandungan biomassa tiap bagian pohon.

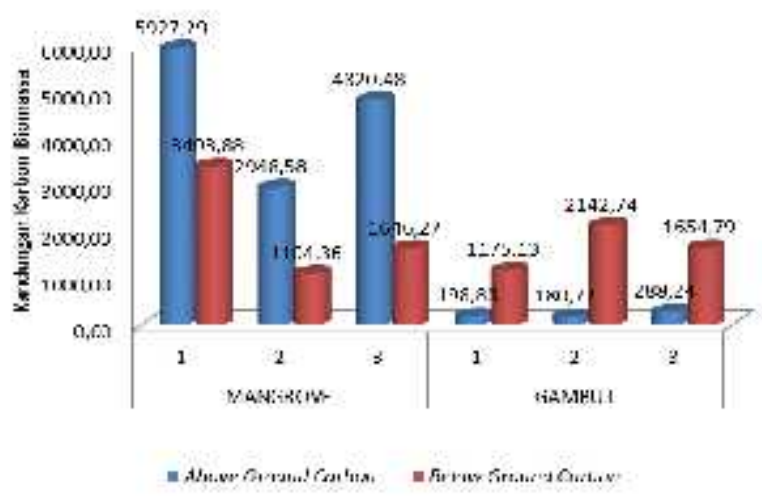

Grafik 2. Kandungan Karbon Biomassa di masing-masing stasiun

Total karbon biomassa vegetasi tertinggi pada wilayah mangrove terdapat di Stasiun I. Sedangkan kandungan biomassa dan karbon terendah terdapat pada Stasiun II. Perbedaan kandungan biomassa tersebut dapat disebabkan oleh berbagai faktor lingkungan seperti kerapatan vegetasi mangrove yang tinggi dengan ukuran diameter pohon yang relatif besar, sehingga jumlah kandungan biomassa dan karbon pada Stasiun I tersebut juga besar. Selanjutnya di wilayah gambut pada Stasiun II lebih besar dari pada stasiun lainnya yaitu 4.646,92 ton/ha. Sedangkan stasiun yang memiliki total biomassa terendah adalah Stasiun I, dengan total biomassa 2.748,01 ton/ha. Hal ini diduga karena pada Stasiun II memiliki jumlah biomassa vegetasi tumbuhan dan nekromassa yang besar dimana lokasi stasiun II tersusun dari vegetasi sagu yang telah ditanam selama lima tahun dan vegetasi lain yang memiliki diameter lebih besar serta serasah yang berada di permukaan tanah.

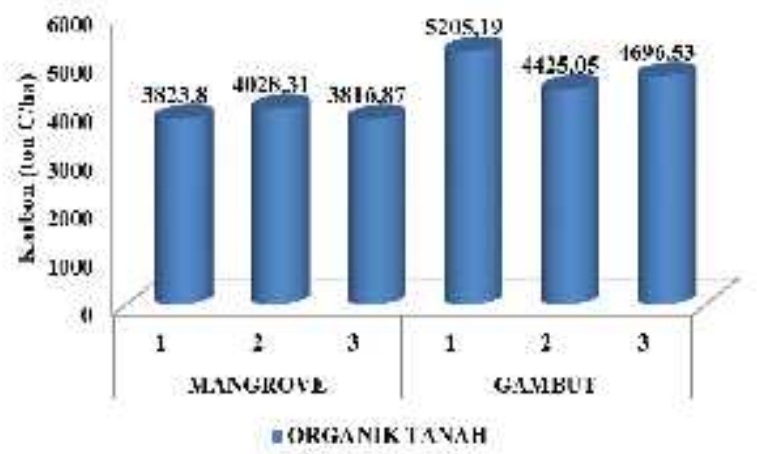

Grafik 3. Gambaran Kandungan Karbon Organik Tanah di masing-masing stasiun

Estimasi total kandungan karbon organik tanah pada wilayah gambut tertinggi terdapat di Stasiun I yang berada di kawasan perkebunan karet dengan kandungan karbon organik tanah 
sebesar 5.205,2 ton C/ha. Stasiun yang memiliki kandungan karbon organik tanah terendah terdapat pada Stasiun II yang berada di daerah kebun sagu dengan kandungan karbon organik tanah sebesar 4.425,05 ton $\mathrm{C} / \mathrm{ha}$. Perbedaan ini diduga dipengaruhi oleh tipe kedalaman gambut.

Selanjutnya kandungan karbon organik tanah pada wilayah mangrove tertinggi terdapat di Stasiun II yang berada di kawasan Pelabuhan dengan kandungan karbon organik tanah sebesar 4.028,31 ton $\mathrm{C} / \mathrm{ha}$. Stasiun yang memiliki kandungan karbon organik tanah terendah terdapat pada Stasiun III dengan kandungan karbon organik tanah sebesar 3.816,87 ton $\mathrm{C} / \mathrm{ha}$. Perbedaan nilai kandungan organik tanah pada masing-masing stasiun ini diduga disebakan oleh kondisi tekstur sedimen mangrove yang didukung oleh melimpahnya sisa-sisa serasah yang mengendap dan tidak terbasahi oleh air yang kemudian menyebabkan serasah tersebut tertahan dan menumpuk. Sehingga dapat dikatakan bahwa pasang surut pada masingmasing stasiun juga turut mempengaruhi jumlah simpanan karbon dalam sedimen mangrove.

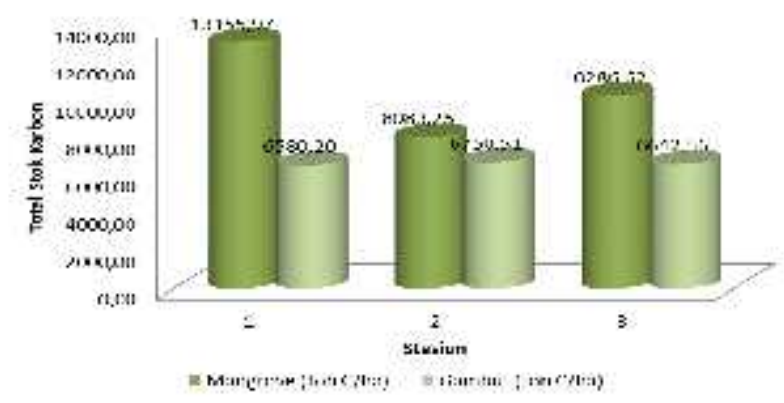

Grafik 4. Perbandingan Total Stok Karbon Yang Tersimpan Di Ekosistem Lahan Basah Desa Sungai Tohor

Hasil penelitian menunjukkan bahwa total stok karbon yang tersimpan pada ekosistem lahan basah yang melingkupi wilayah mangrove hingga wilayah gambut yakni $51.499,10$ ton $\mathrm{C} / \mathrm{ha}$. Total simpanan karbon terbesar berada pada wilayah mangrove yakni sebesar 31.525,83 ton $\mathrm{C} / \mathrm{ha}$, dimana nilai kandungan karbon tertinggi berada pada Stasiun I dengan nilai $13.155,97$ ton $\mathrm{C} /$ ha sedangkan nilai terendah pada Stasiun II dengan nilai $8.083,25$ ton $\mathrm{C} / \mathrm{ha}$. Sementera itu, dari hasil penelitian ini di wilayah gambut memiliki kemampuan menyimpan karbon yang lebih rendah dengan nilai total $19.973,27$ ton $\mathrm{C} / \mathrm{ha}$ dimana pada Stasiun II memiliki nilai terbesar dengan nilai $6.750,51$ ton $\mathrm{C} /$ ha sedangkan yang terendah terdapat pada Stasiun I dengan nilai $6.580,20$ ton $\mathrm{C} / \mathrm{ha}$.

\section{Daya Serap Gas $\mathrm{CO}_{2}$ Pada Ekosistem Lahan} Basah Desa Sungai Tohor. Adapun total gas $\mathrm{CO}_{2}$ yang terserap pada ekosistem lahan basah Desa Sungai Tohor yakni 70.901,78 ton $\mathrm{CO}_{2} /$ ha. Total serapan tertinggi berada pada wilayah mangrove yakni sebesar 50.219,95 $\mathrm{CO}_{2}$ /ha bila dibandingkan dengan wilayah gambut yakni sebesar 20.681,83 $\mathrm{CO}_{2} / \mathrm{ha}$.

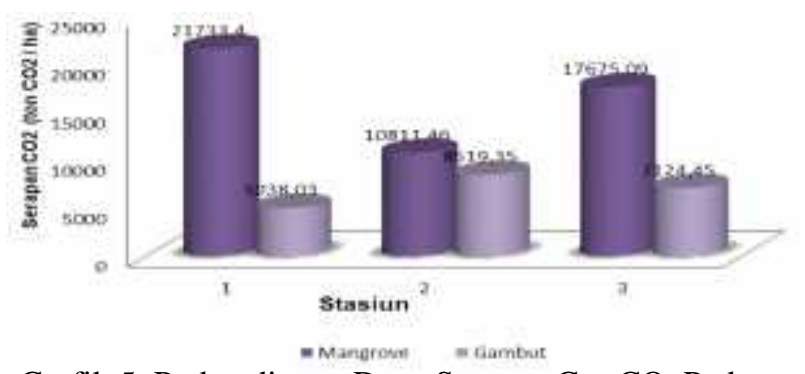

Grafik 5. Perbandingan Daya Serapan Gas $\mathrm{CO}_{2}$ Pada Masing-Masing Stasiun

\section{PEMBAHASAN}

Parameter Kualitas Perairan. Berdasarkan hasil penelitian nilai parameter suhu masingmasing stasiun menunjukkan. Kisaran parameter kualitas perairan ini masih merupakan kisaran yang baik bagi kelangsungan hidup tanaman mangrove.

Komposisi Vegetasi dan Nilai Kerapatan. Hasil penelitian menunjukkan bahwa wilayah mangrove memiliki tingkat keanekaragaman vegetasi yang rendah namun memiliki nilai kerapatan yang tinggi. Sebaliknya, wilayah gambut memiliki tingkat keanekaragaman vegetasi yang tinggi namun memiliki nilai kerapatan yang rendah. Jenisjenis yang dominan dalam suatu kawasan akan menyatakan besaran jumlah individu sejenis yang ditemukan dalam luasan kawasan tersebut. Selanjutnya dominansi spesies tersebut dapat dijadikan sebagai salah satu indikator untuk mengestimasi potensi simpanan karbon di masing-masing wilayah. Namun demikian dominansi jenis spesies yang ditemukan tidak tersebar secara merata pada masing-masing stasiun. 
B. farviflora sebagai spesies yang paling dominan ditemukan pada wilayah mangrove hanya sedikit sekali ditemukan pada Stasiun 2 dimana spesies $A$. alba ternyata lebih mendominasi pada stasiun tersebut. Begitupun halnya pada wilayah gambut jenis spesies yang paling dominan ditemukan adalah Pelara dengan jumlah individu sebanyak 68 individu. Sebanyak 57 individu ternyata ditemukan hanya pada Stasiun 3 dan sisanya berada pada Stasiun 1 dan Stasiun 2. Pada Stasiun 1 spesies yang lebih medominasi adalah Mahang sebanyak 24 individu. Sedangkan pada Stasiun 2 lebih didominasi oleh tanaman Karet yakni sebanyak 9 individu.

Total Stok Karbon yang Tersimpan Pada Ekosistem Lahan Basah. Hasil penelitian menunjukkan bahwa total stok karbon yang tersimpan pada ekosistem lahan basah yang melingkupi wilayah mangrove hingga wilayah gambut yakni $51.499,10$ ton C/ha. Total simpanan karbon terbesar berada pada wilayah mangrove yakni sebesar $31.525,83$ ton $\mathrm{C} / \mathrm{ha}$, Sementera itu, dari hasil penelitian ini di wilayah gambut memiliki kemampuan menyimpan karbon yang lebih rendah dengan nilai total $19.973,27$ ton $\mathrm{C} / \mathrm{ha}$. Perbedaan nilai estimasi stok karbon pada masing-masing wilayah dapat disebabkan perbedaan nilai kandungan biomassanya. Hal ini dikarenakan bahwa $50 \%$ dari biomassa adalah karbon. Chanan (2012) menyatakan, setiap penambahan kandungan biomassa akan diikuti oleh penambahan kandungan stok karbon. Hal ini menjelaskan bahwa karbon dan biomassa memiliki hubungan yang searah sehingga apapun yang menyebabkan peningkatan ataupun penurunan biomassa maka akan menyebabkan peningkatan atau penurunan kandungan stok karbon.

Selanjutnya, menurut Rahayu et al (2007), jumlah karbon tersimpan dalam suatu kawasan dapat dipengaruhi oleh jumlah kerapatan vegetasinya, semakin rapat vegetasi pada lahan tersebut maka semakin banyak jumlah karbon yang tersimpan. Dengan kata lain kerapatan vegetasi di wilayah mangrove berbanding lurus terhadap kandungan biomassa mangrove dimana semakin tinggi kerapatan mangrove maka akan semakin tinggi pula kandungan biomassanya serta semakin tinggi pula jumlah karbon yang tersimpan di dalamnya.

\section{Daya Serap Gas $\mathrm{CO}_{2}$ Pada Ekosistem Lahan Basah Desa Sungai Tohor.} Peningkatan serapan gas $\mathrm{CO}_{2}$ oleh tanaman pada ekosistem lahan basah Desa Sungai Tohor dapat dipengaruhi oleh berbagai faktor seperti umur, ukuran diameter dan tinggi tanaman tersebut. Besarnya jumlah karbon yang terikat dalam suatu tanaman dapat menggambarkan seberapa besar kemampuan tanaman tersebut dalam mengikat gas $\mathrm{CO}_{2}$ dari atmosfer.

Adapun total gas $\mathrm{CO}_{2}$ yang terserap pada ekosistem lahan basah Desa Sungai Tohor yakni $70.901,78$ ton $\mathrm{CO}_{2} /$ ha. Total serapan tertinggi berada pada wilayah mangrove yakni sebesar 50.219,95 $\mathrm{CO}_{2}$ /ha bila dibandingkan dengan wilayah gambut yakni sebesar $20.681,83$ $\mathrm{CO}_{2}$ /ha. Perbedaan nilai serapan gas $\mathrm{CO}_{2}$ ini berkaitan dengan komposisi vegetasi dan kerapatannya pada masing-masing wilayah tersebut. Pada wilayah mangrove, meskipun keanekaragamannya rendah, namun memiliki nilai kerapatan vegetasi yang tinggi berpotensi dalam peningkatan serapan gas $\mathrm{CO}_{2} /$ ha di wilayah tersebut.

Sebaliknya, berdasarkan hasil penelitian diketahui bahwa daya serap $\mathrm{CO}_{2}$ /ha vegetasi gambut lebih rendah dibandingkan pada vegetasi mangrove. Hal ini disebabkan oleh kerapatan vegetasinya yang rendah akibat dari sebaran individu vegetasi yang tidak merata. Namun demikian, daya serap vegetasi gambut masih lebih besar dibandingkan dengan vegetasi yang berada pada hutan alam.

Nilai serapan $\mathrm{CO}_{2}$ yang tinggi oleh vegetasi pada wilayah mangrove menggambarkan kemampuan vegetasi mangrove untuk memfiksasi $\mathrm{CO}_{2}$ yang kemudian disimpan dalam bentuk cadangan karbon pada tegakan pohon. Daya serap yang berbeda pada wilayah mangrove dan wilayah gambut diduga dipengaruhi oleh kondisi iklim, topografi jenis vegetasi dan kerapatan vegetasinya. Rahayu et al., (2010) menyebutkan bahwa kemampuan hutan dalam menyerap karbon tidaklah sama tergantung dari tipe hutan, jenis pohon, tipe tanah dan tofografinya. 


\section{SIMPULAN}

Berdasarkan hasil penelitian dapat disimpulkan bahwa jumlah total stok karbon yang tersimpan pada ekosistem lahan basah Desa Sungai Tohor yakni sebesar $51.499,10$ ton $\mathrm{C} / \mathrm{ha}$. Total simpanan karbon terbesar berada pada wilayah mangrove yakni sebesar 31.525,83 ton $\mathrm{C} /$ ha dan di wilayah gambut memiliki kemampuan menyimpan karbon yang lebih rendah dengan nilai total $19.973,27$ ton $\mathrm{C} / \mathrm{ha}$.

Besaran simpanan karbon tersebut didukung oleh tinggi nilai kerapatan vegetasi dan daya serap gas $\mathrm{CO}_{2}$. Total simpanan karbon yang didapatkan menunjukkan bahwa ekosistem lahan basah Desa Sungai Tohor memiliki potensi dan kontribusi yang cukup besar dalam menyimpan karbon terutama pada wilayah mangrove.

\section{UCAPAN TERIMA KASIH}

Ucapan terimakasih penulis sampaikan kepada pemerintah dan masyarakat desa sungai tohor yang telah memberikan informasi dan data yang penulis butuhkan selama melakukan kegiatan penelitian di desa sungai tohor, serta semua pihak yang turut membantu sehingga terlaksananya penelitian ini.

\section{DAFTAR PUSTAKA}

Badan Standardisasi Nasional. 2011. SNI 7724 - Pengukuran dan Penghitungan Cadangan Karbon - Pengukuran Lapangan untuk Penaksiran Cadangan Karbon Hutan (Ground Based Forest Carbon Accounting). Badan Standarisasi Nasional.

Chanan, M. 2012. Pendugaan cadangan karbon (C) tersimpan di atas permukaan tanah pada vegetasi hutan tanaman jati (Tectona grandis Linn.F) (Di RPH Sengguruh BKPH Sengguruh KPH Malang Perum Perhutani II Jawa Timur). Jurnal Gamma 7(2): 61-73.

Heriyanto, N. M. dan E. Subiandono, 2012. Komposisi dan Struktur Tegakan, Biomasa, dan Potensi Kandungan Karbon Hutan Mangrove di TAMAN Nasional
Alas Purwo. Jurnal Penelitian Hutan dan Konservasi Alam, 9 (1): 23 - 32.

Hairiah K, dan Rahayu S. 2007. Pengukuran Karbon Tersimpan di Berbagai Penggunaan Lahan. Buku. World Agroforestry Center-ICRAF. Bogor. 77p

Istomo, 2006. Kandungan fosfor dan kalsium pada tanah dan biomassa hutan rawa gambut (Studi kasus di wilayah HPH PT. Diamond Raya Timber, bagan Siapi-api, Provinsi Riau. Jurnal Manajemen Hutan Tropika. 12(3), pp. 40-57.

Kauffman et al.,, Protocols for the measurement, monitoring, and reporting of structure, biomass, carbon stocks and greenhouse gas emissions in tropical peat swamp forests (2016). Working Paper 221. Bogor, Indonesia.

Komiyama, A., J. E. Ong, S. Poungparn. 2008. Allometry, Biomassa and Productivity of Mangrove Forest : A Review. Aquatic Botany. Vol. 89 : 128-137.

Rahayu, S., Noordjwik, M. V dan Lusiana, B. 2010. Pendugaan Cadangan Karbon di Atas Permukaan Tanah pada Berbagai Sistem Penggunaan Lahan di Kabupaten Nunukan, Kalimantan Timur. Buku. World Agroforestry Centre. Bogor. 88 hlm.

Soerianegara, I. dan A. Indrawan. 2005. Ekologi Hutan Indonesia. Institut Pertanian Bogor. Bogor.

Sugiyono, 2007. Metode Penelitian Pendidikan Pendekatan Kuantitatif dan Kualitatif. Bandung; Alfabeta.

Suryanta J, Turmudi, Irmadi Nahib, dan Yatin Suwarno 2016. Kajian Cadangan Karbon Lahan Gambut Kabupaten Kepulauan Meranti. Bogor. 